\title{
Gp100-Fowlpox Vaccine
}

National Cancer Institute

\section{Source}

National Cancer Institute. gp100-Fowlpox Vaccine. NCI Thesaurus. Code C2761.

A cancer vaccine comprised of a recombinant fowlpox virus vector encoding the

melanoma antigen glycoprotein 100 (gp 100) with potential antineoplastic activity. The expression of gp100 may generate a cellular immune response to melanoma cells; this effect is enhanced by the co-administration of interleukin 2 (IL-2). ( $\mathrm{NClO4)}$ 